\title{
Analisa Dan Perancangan Jaringan Wireless Local Area Network Pada SMK Negeri 1 Rengat Barat
}

\author{
Apri Siswanto ${ }^{1}$, Kusmeli $^{2}$, Evizal Abdul Kadir ${ }^{3}$ \\ Program Studi Teknik Informatika, Fakultas Teknik, Universitas Islam Riau ${ }^{1,2,3}$ \\ aprisiswanto@eng.uir.ac.id ${ }^{1}$, kusmeli91@gmail.com², evizal@eng.uir.ac.id ${ }^{3}$
}

\begin{tabular}{l} 
Article Info \\
\hline History : \\
Dikirim 03 September 2018 \\
Direvisi 31 Oktober 2018 \\
Diterima 20 November 2019 \\
\hline
\end{tabular}

Kata Kunci :

Jaringan Komputer

WLAN

Telekomunikasi

Rengat

\begin{abstract}
Abstrak
Jaringan komputer adalah jaringan yang memungkinkan komputer berkomunikasi satu sama lain dengan bertukar data. Dalam hal ini jaringan komputer telah banyak digunakan untuk membantu dunia dalam membantu transmisi data antar komputer satu sama lain untuk bekerja. SMKN 1 Rengat Barat adalah sekolah yang akan mengembangkan jaringan komputer untuk mengakses data dari setiap komputer di SMK N 1 Rengat Barat dengan menggunakan jaringan WLAN dimana penghubung antara komputer dengan satu komputer di SMKN 1 Rengat menggunakan data transmisi udara menggunakan frekuensi radio pengembangan teknologi WLAN SMKN 1 Rengat Barat tidak lagi menggunakan kabel dalam menghubungkan satu komputer ke komputer lainnya. Dalam perkembangan teknologi WLAN dapat memudahkan dalam kegiatan berbagi data antar komputer di SMKN 1 Rengat Barat dan juga aksesibilitas siswa SMKN 1 Rengat Barat dalam proses pembelajaran.
\end{abstract}

(C) This work is licensed under a Creative Commons AttributionShareAlike 4.0 International License.

\section{Koresponden:}

Apri Siswanto,

Program Studi Teknik Informatika, Fakultas Teknik

Universitas Islam Riau,

Jl. Kaharuddin Nasution No.113, Pekanbaru, Riau

Email : aprisiswanto@eng.uir.ac.id

\section{PENDAHULUAN}

Dewasa ini perkembangan teknologi tidak lepas dari jaringan komputer. Jaringan komputer adalah sebuah sistem yang terdiri atas komputer, software dan perangkat jaringan yang bekerja bersama-sama untuk mencapai suatu tujuan yang sama setiap bagian meminta dan memberikan layanan service pihak yang meminta layanan disebut client dan yang memberi layanan disebut server [1].

Teknologi komputer sudah merambah keberbagai bidang termasuk pendidikan. Sebagian sekolah memiliki komputer untuk mempercepat proses kerja administrasi akademik. Bahkan sudah ada yang memanfaatkan teknologi komputer untuk mendukung proses pembelajaran komputer dijadikan untuk menyampaikan konsep keilmuan menjadi lebih menarik dan mudah diterima oleh murid. Tidak hanya itu saja, saat ini sudah banyak sekolah yang memiliki jaringan komputer yang terhubung jaringan lokal kejaringan intranet [2-5].

Demikian juga di SMKN 1 Rengat Barat, karena kepentingan sekolah disana sangat membutuhkan jaringan komputer yang digunakan untuk printer sharing, jaringan intranet, 
Tranportasi data dari setiap komputer maupun hal-hal lain yang memerlukan komputerisasi. Sehubungan dengan hal itu penggunaan jaringan WLAN mempunyai peranan yang sangat penting dalam transportasi data di sekolah tersebut.

Dengan WLAN dimana hubungan antar komputer dilakukan media transmisi data udara dengan menggunakan frekuensi radio [6]. Dengan teknologi WLAN memungkinkan para pengguna komputer terhubung tanpa kabel ke dalam jaringan. SMKN 1 Rengat Barat selama ini belum memiliki jaringan. Sehingga komputer maupun perangkat lain di sekolah tersebut belum saling terkoneksi antar bagiannya. Tentu saja hal ini sangat tidak fleksibel dan mengganggu mobilitas maupun kenyamanan dari sekolah tersebut. Untuk memberikan solusi dari permasalahan tersebut, maka paper memaparkan dan menjelaskan analisa dan perancangan jaringan WLAN Pada SMKN 1 Rengat Barat.

\section{METODE PENELITIAN}

Metodologi yang digunakan dalam penelitian ini adalah eksperimental yang dibagi menjadi empat tahap yaitu pengumpulan data, tinjauan pustaka, perancangan dan pengujian jaringan wireless [7].

\subsection{Pengumpulan Data}

Adapun teknik pengumpulan data yang diperlukan dalam penelitian ini diperoleh dari studi pustaka, mencari referensi-referensi ke pustaka sebagai pedoman penelitian yang penulis lakukan baik berupa buku maupun literatur yang berhubungan dengan penelitian

\subsection{Tinjauan Pustaka}

Teori yang yang digunakan pada penelitian ini dapat diuraikan sebagai berikut :

\subsubsection{QoS (Quality of Service)}

Quality of Service (QoS) merupakan kemampuan suatu jaringan untuk menyediakan layanan yang lebih baik kepada pengguna dalam membagi bandwidth sesuai dengan kebutuhan data yang digunakan. QoS merupakan terminologi yang digunakan untuk mendefinisikan kemampuan suatu jaringan untuk menyediakan tingkatan jaminan layanan yang berbeda-beda. Berbagai aplikasi memiliki jenis dan kebutuhan yang berbeda-beda. Misalnya transaksi data bersifat sensitif terhadap distorsi tetapi kurang sensitif terhadap delay, packet loss dan throughput. Sebaliknya, komunikasi bersifat sensitif terhadap tundaan dan kurang sensitif terhadap kesalahan.

\subsubsection{Delay}

Delay adalah waktu yang dibutuhkan oleh sebuah paket data terhitung dari saat pengiriman oleh transmisitter sampai saat diterima oleh reciver. Beberapa jenis delay di antaranya adalah: rumus untuk delay adalah sebagai berikut:

$$
\text { Delay }=\frac{\text { waktu pengiriman paket }}{\text { total paket yang diterima }}
$$

1. Propagation delay (delay yang terjadi akibat transmisi melalui jarak antara pengirim dan penerima).

2. Serialization delay (delay pada saat proses peletakan bit kedalam circuit)

3. Packetization delay (delay yang terjadi pada saat proses coding, compression, decompression dan decoding).

4. Queuing delay (delay akibat waktu tunggu paket sampai dilayani).

5. Jitter buffer (delay akibat adanya buffer untuk mengatasi jitter). 
Tabel 1. Delay Standar THIPON [8]

\begin{tabular}{lcc}
\hline $\begin{array}{c}\text { Kategori } \\
\text { Latensi }\end{array}$ & Besar Delay & Indeks \\
\hline Sangat bagus & $<150 \mathrm{~ms}$ & 4 \\
\hline Bagus & $150 \mathrm{~s} / \mathrm{d} 300 \mathrm{~ms}$ & 3 \\
\hline Sedang & $300 \mathrm{~s} / \mathrm{d} 450 \mathrm{~ms}$ & 2 \\
\hline Tidak Bagus & $>450 \mathrm{~ms}$ & 1 \\
\hline
\end{tabular}

\subsubsection{Throughput}

Troughput adalah kecepatan (rate) transfer data efektif, yang diukur dalam bps. throughput merupakan jumlah total kedatangan paket yang sukses yang diamati pada tujuan selama interval waktu tertentu dibagi oleh durasi interval waktu tersebut. Adapun rumus throughput adalah sebagai berikut :

$$
\text { Throughput }=\frac{\text { jumlah data yang dikirim }}{\text { waktu pengiriman paket }} \times 8
$$

Tabel 2. Throghput standar THIPON

\begin{tabular}{lcc}
\hline \multicolumn{1}{c}{$\begin{array}{c}\text { Kategori } \\
\text { Throughput }\end{array}$} & Throughput & Indeks \\
\hline Sangat Bagus & $100 \%$ & \\
Bagus & $75 \%$ & 4 \\
Sedang & $50 \%$ & 3 \\
Tidak Bagus & $<25 \%$ & 2 \\
\hline
\end{tabular}

\subsubsection{Packet Loss}

Packet loss adalah banyaknya paket yang hilang selama proses tranmisi ke tujuan. Packet loss terjadi ketika peak load dan congestin (kemacetan transmisi paket akibat padatnya traffic yang harus dilayani) dalam batas waktu tertentu,maka frame (gabungan data payload dan header yang ditranmisikan) data akan dibuang sebagaimana perlakuan terhadap frame data pada jaringan berbasis Internet Protokol (IP) [9]-[11]. Adapun rumus mencari nilai packet loss yaitu:

$$
\text { Packet Loss }=\frac{\text { Data yang dikirim-Paket data yang diterima }}{\text { waktu pengiriman paket }} X 100 \%
$$

Tabel 3. Packet Loss standar THIPON

\begin{tabular}{lcc}
\hline \multicolumn{1}{c}{$\begin{array}{c}\text { Kategori } \\
\text { Degradasi }\end{array}$} & Packet Loss & Indeks \\
\hline Sangat bagus & $0 \%$ & 4 \\
Bagus & $3 \%$ & 3 \\
Sedang & $15 \%$ & 2 \\
Tidak Bagus & $25 \%$ & 1 \\
\hline
\end{tabular}

\section{HASIL DAN PEMBAHASAN}

\subsection{Pengujian Streaming Video}


Pengujian streaming video dilakukan dengan streaming video dari server ke client yang sudah terhubung kejaringan WLAN streaming video akan dicatat throughput, packet loss dan delay menggunkan wireshark .

\subsubsection{Pengujian Pertama}

Hasil pengujian pada Throughput saat Video Streaming dijalankan .dengan Throughput 0,534 Mbit/sec dijelaskan pada Gambar 1.

\begin{tabular}{|c|c|c|c|c|c|}
\hline \multicolumn{6}{|l|}{$\begin{array}{l}\text { Display } \\
\text { Display filter: } \\
\text { Ignored packets: }\end{array}$} \\
\hline Traffic & A Captured & 1 Displayed 4 & Displayed $\% 1$ & Marked 1 & Marked $\%$ \\
\hline Packets & 7463 & 7463 & $100.000 \%$ & 0 & $0,000 \%$ \\
\hline \multicolumn{6}{|c|}{ Between first and last packet $149,058 \mathrm{sec}$} \\
\hline Avg packets/sec & 50,068 & & & & \\
\hline Avg. packet size & $1333,216 \mathrm{~b}$ & ytes & & & \\
\hline Bytes: & 9949791 & 9949791 & $100.000 \%$ & 0 & $0.000 \%$ \\
\hline Avg bytes $/ \mathrm{sec}$ & 66751,185 & & & & \\
\hline Avg. MBit/sec & 0,534 & & & & \\
\hline
\end{tabular}

Gambar 1. Pengujian Throughput Video1

Pada gambar 2 total dari delay 147,40 second, dan total paket yang diterima adalah 41407. Sehingga jika dihitung sesuai dengan rumus. Rata-rata delay $=147,40 \mathrm{/}$ $41407=0,00355978458$ detik.

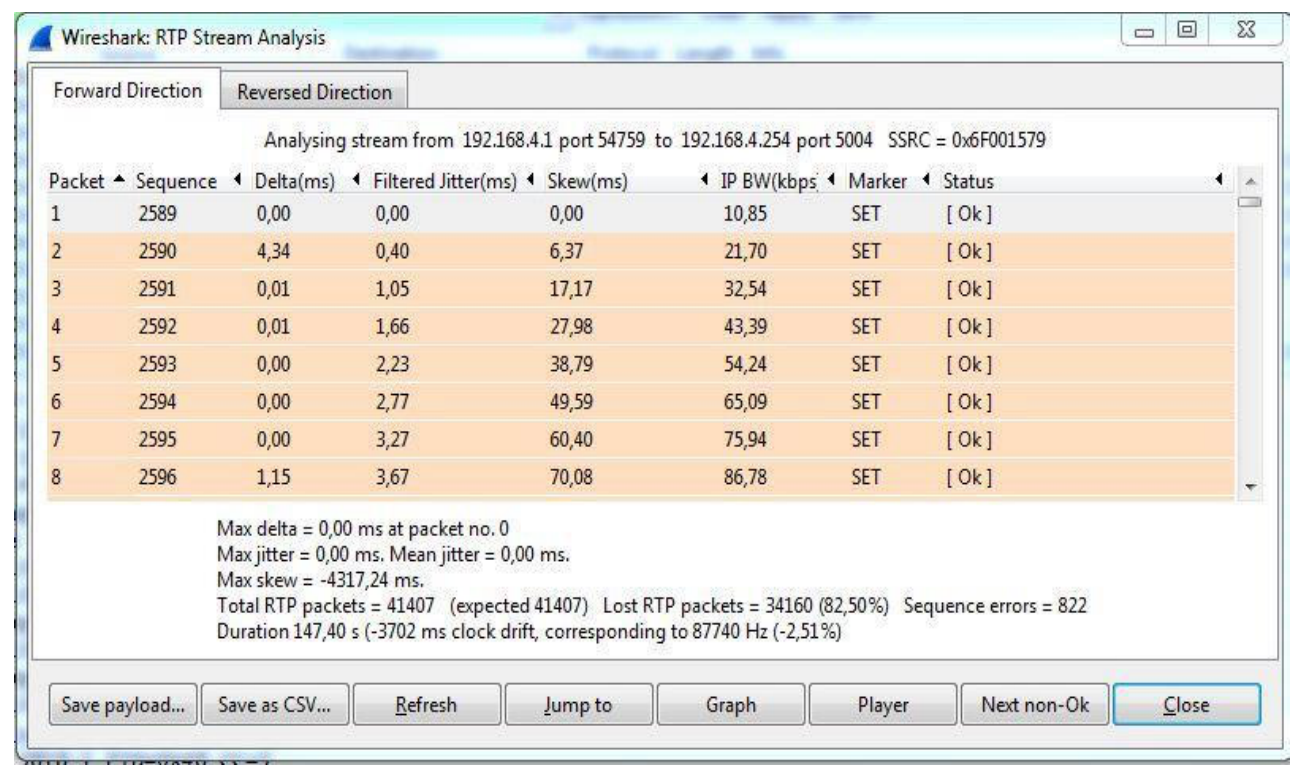

Gambar 2. Pengujian Packet Loss Video 1 


\subsubsection{Pengujian Kedua}

Hasil pengujian pada Throughput saat Video Streaming dijalankan .dengan Throughput 0,349Mbit/sec dijelaskan pada Gambar 3.

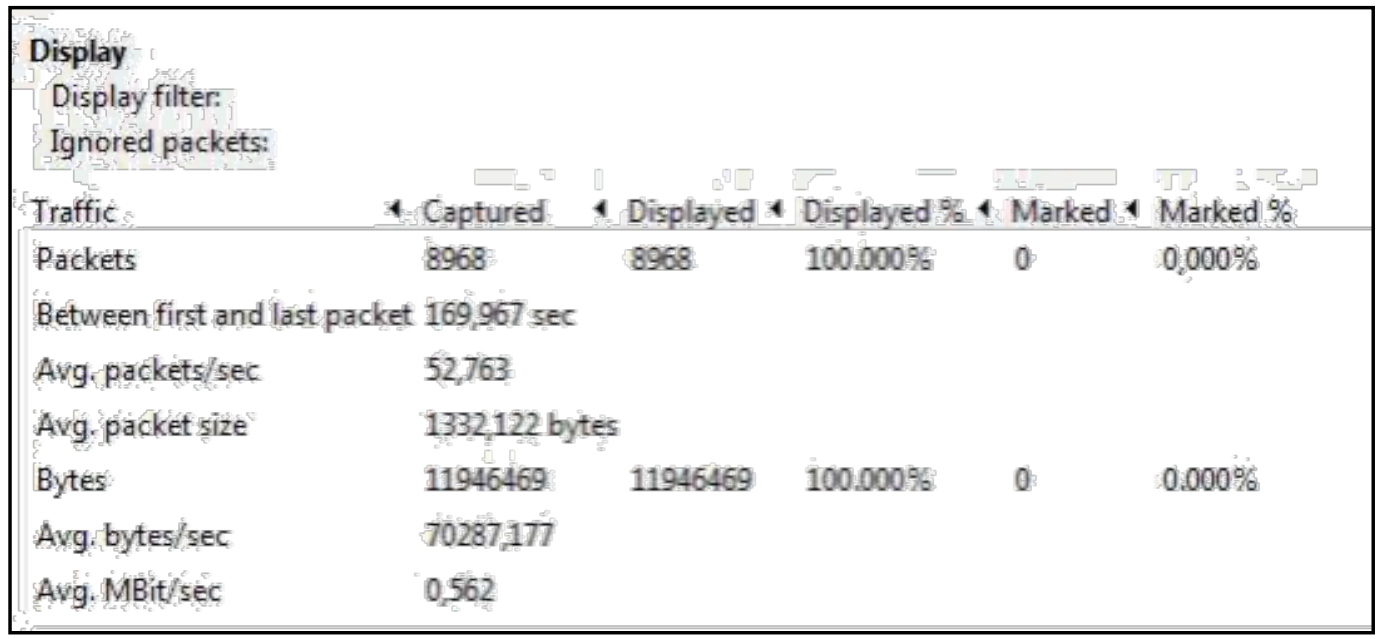

Gambar 3. Pengujian Throughput Video 2

Pada gambar 4 total dari delay 156,14 second, dan total paket yang diterima adalah 5121 . Sehingga jika dihitung sesuai dengan rumus. Rata-rata delay $=156,14 / 5121=0,0304901386$ detik.

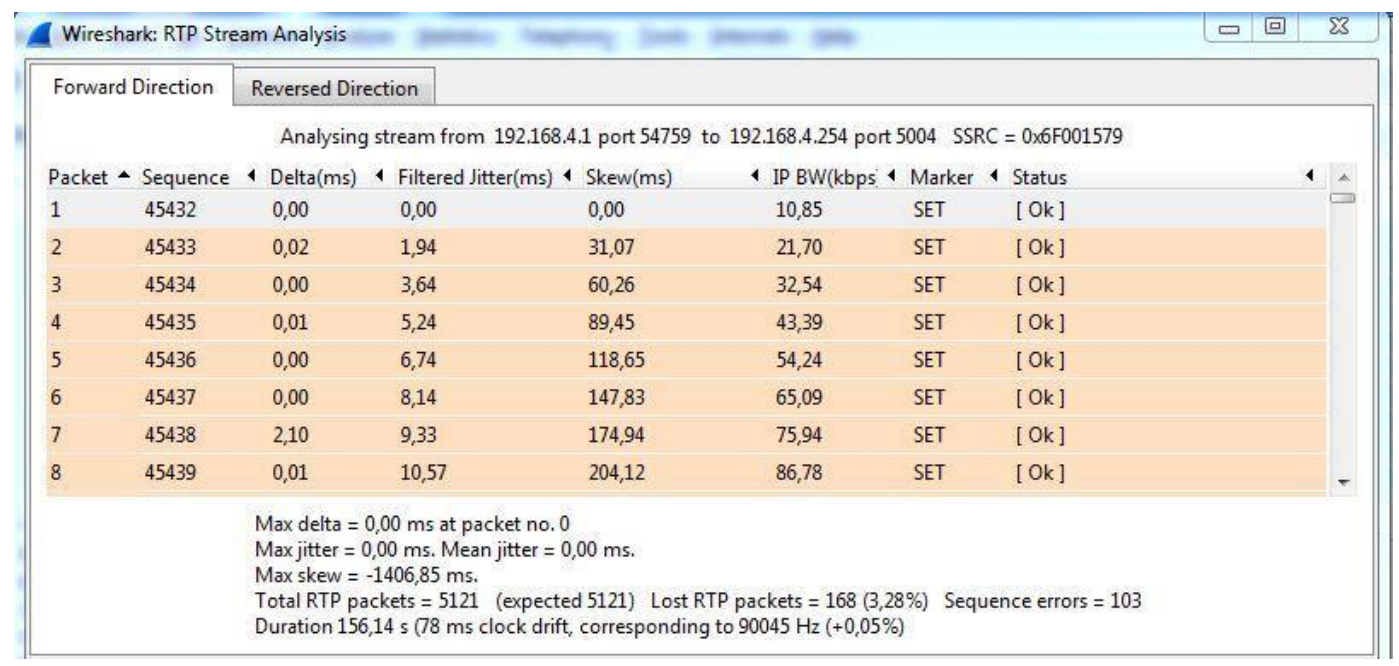

Gambar 4. Pengujian Packet Loss Video 2

\subsubsection{Pengujian Ketiga}

Hasil pengujian pada Throughput saat Video Streaming dijalankan .dengan Throughput 0,562 Mbit/sec dijelaskan pada Gambar 5. 


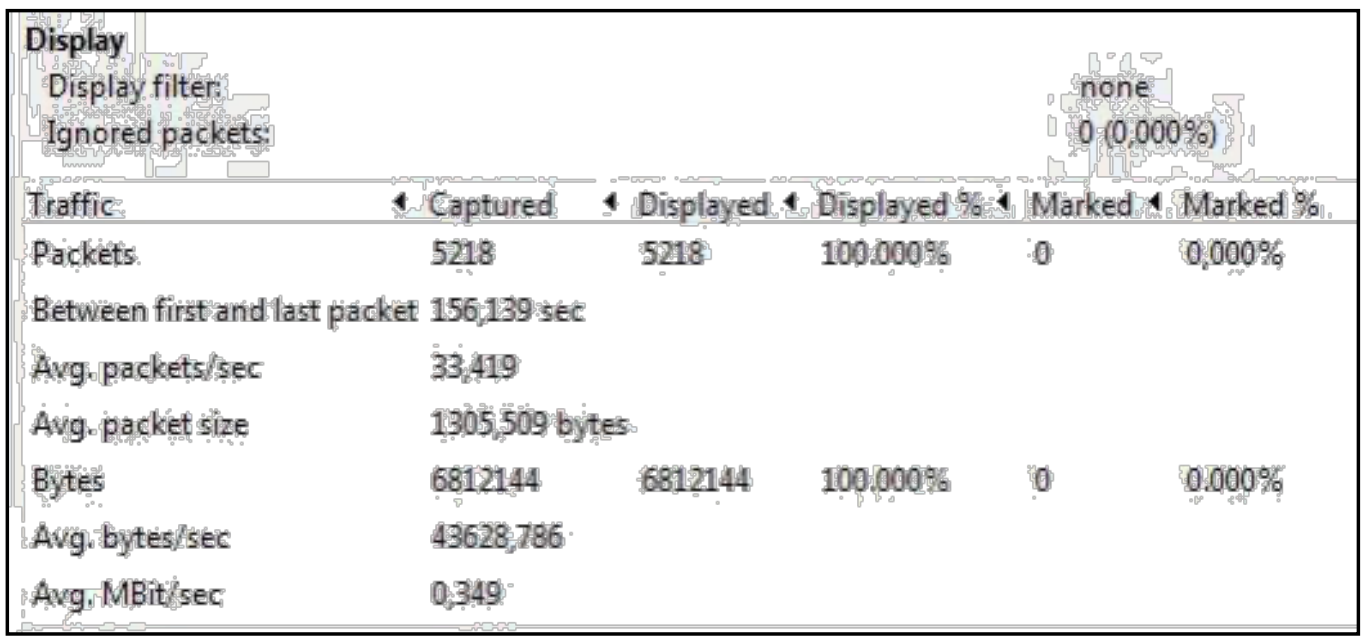

Gambar 5. Pengujian Throughput Video 3

Pada gambar 6 total dari delay 169,97 second, dan total paket yang diterima adalah 13973. Sehingga jika dihitung sesuai dengan rumus. Rata-rata delay $=169,97 / 13973=$ 0,012141738 detik.

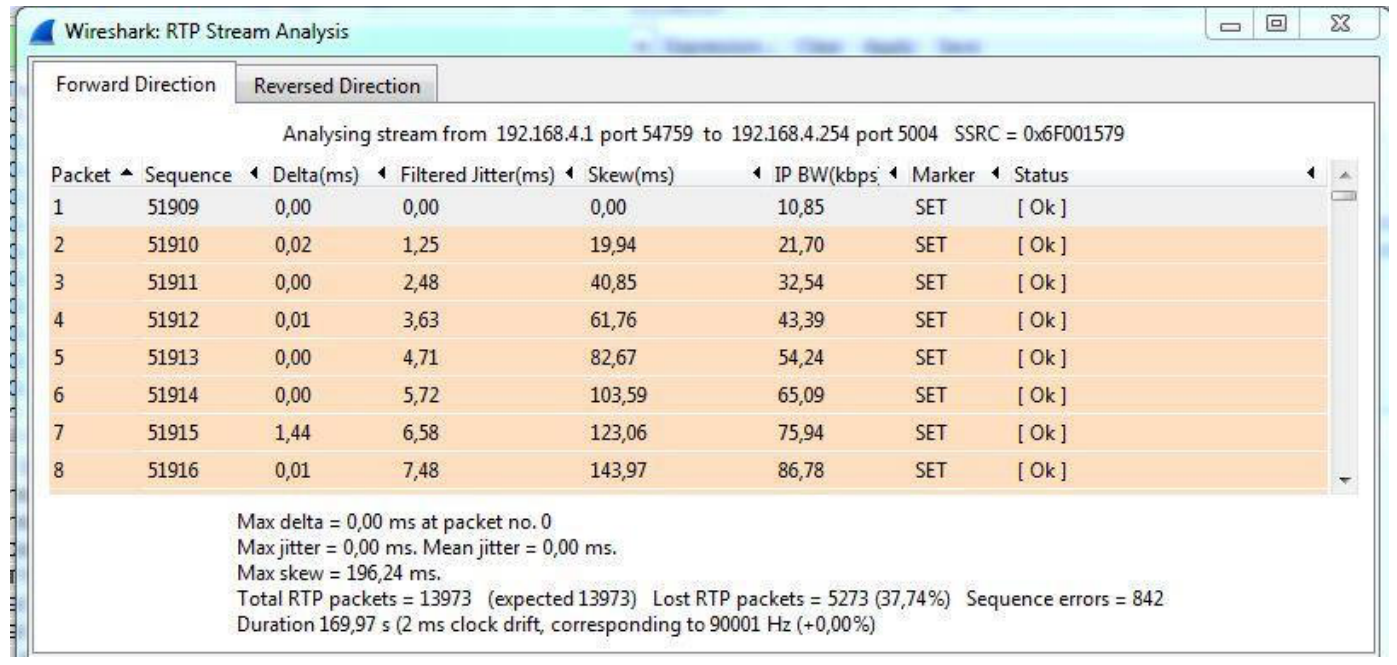

Gambar 6. Pengujian Packet Loss Video 3

\subsubsection{Pengujian Keempat}

Hasil pengujian pada Throughput saat Video Streaming dijalankan .dengan Throughput 0,264 Mbit/sec dijelaskan pada Gambar 7. 


\begin{tabular}{|c|c|c|c|c|c|c|}
\hline \multicolumn{7}{|l|}{$\begin{array}{l}\text { Display filter: } \\
\text { Ignored packets: }\end{array}$} \\
\hline Traffic & 1 & Captured 1 & 1 Displayed 1 & Displayed $\%$ & Marked 4 & Marked $\%$ \\
\hline Packets: & & 4487 & 4487 & $100.000 \%$ & 0 & $0,000 \%$ \\
\hline \multicolumn{7}{|c|}{ Between first and last packet $174,781 \mathrm{sec}$} \\
\hline Avg. packets/sec & & 25,672 & & & & \\
\hline Avg. packet size & & 1285,171 bytes & & & & \\
\hline Bytes & & 5766563 & 5766563 & $100.000 \%$ & 0 & $0.000 \%$ \\
\hline Avg. bytes/sec & & 32993,164 & & & & \\
\hline Avg, MBit/sec & & 0,264 & & & & \\
\hline
\end{tabular}

Gambar 7. Pengujian Througput Video 4

Pada gambar 8 total dari delay 174,78 second, dan total paket yang diterima adalah 4609 . Sehingga jika dihitung sesuai dengan rumus. Rata-rata delay $=174,78 / 4609=0,012141738$ detik.

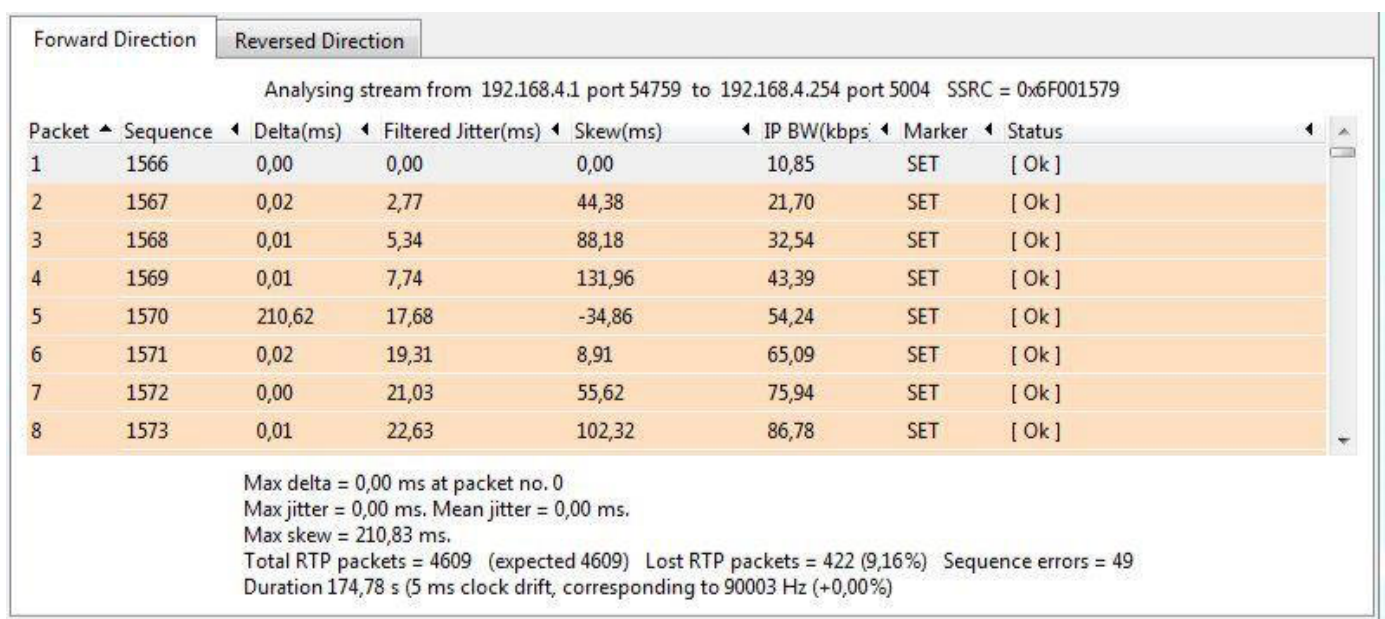

Gambar 8. Pengujian Packet Loss Video 4

Berdasarkan hasil pengujian dengan Streaming video pada aplikasi VLC hasil yang didapat pada throughput, packet loss dan delay dapat dilihat pada tabel 4.

Tabel 4. Hasil Pengujian

\begin{tabular}{rlll}
\hline No & Throughput & \multicolumn{1}{c}{ Packet Loss } & \multicolumn{1}{c}{ Delay } \\
\hline 1 & $0,534 \mathrm{Sec}$ & $82,50 \%$ & $0,00355978458 / \mathrm{Sec}$ \\
2 & $0,349 \mathrm{Sec}$ & $3,28 \%$ & $0,0304901386 / \mathrm{Sec}$ \\
3 & $0,562 \mathrm{Sec}$ & $37,34 \%$ & $0,012141738 / \mathrm{Sec}$ \\
4 & $0,264 \mathrm{Sec}$ & $9,16 \%$ & $0,012141738 / \mathrm{Sec}$ \\
\hline
\end{tabular}

\section{KESIMPULAN}

Dari hasil uraian yang telah dibahas pada tugas akhir dengan judul "Analisa dan Perancangan Jaringan WLAN Pada SMK N 1 Rengat Barat, maka dapat disimpulkan sebagai berikut : 
1. Pada saat melakukan pengujian sebelum download dan pada saat download file ke server terdapat penurunan signifikan terhadap Throughput

2. Pada saat melakukan pengujian dengan ping ke 192.168.4.1 -n 100 packet sent $=100$ dan packet received $=100$ lost $=0$ kesimpulannya pada saat pengiriman tidak ada paket yang lost dan waktu delay $4 \mathrm{~ms}$

\section{SARAN}

1. Dalam pemasangan perangkat mikrotik harus diperhitungkan letak dan ketinggiannya hal ini dilakukan untuk mendapatkan kinerja dan jangkauan sinyal yang maksimal

2. Disarankan untuk mengaktifkan fitur security pada wireless access point untuk meningkatkan keamanan dalam jaringan WLAN

\section{DAFTAR PUSTAKA}

[1] E. Tittel, "Schaum's Outline: Computer Networking (Jaringan Komputer)," Jakarta: Erlangga, 2002.

[2] E. A. Kadir, A. Siswanto, and A. Syukur, "Performance analysis of wireless LAN $802.11 \mathrm{n}$ standard for e-Learning," in Information and Communication Technology (ICoICT), 2016 4th International Conference on, 2016, pp. 1-6.

[3] E. A. Kadir, A. Siswanto, and A. Yulian, "Home Monitoring System Based on Cloud Computing Technology and Object Sensor," in Proceedings of the Second International Conference on the Future of ASEAN (ICoFA) 2017-Volume 2, 2018, pp. 963-972.

[4] A. Siswanto and R. Faldana, "Sistem Monitoring Rumah Berbasis Teknologi Cloud Computing," SESINDO 2014, vol. 2014, 2014.

[5] A. Siswanto and A. Tedyyana, "Manajemen Bandwidth dan Monitoring Akses Data," in Seminar Nasional Teknologi Informasi dan Komunikasi, Medan, 2014, pp. 24-28.

[6] O. W. Purbo, P. Tanuhandaru, N. Noertam, and M. R. Djajadikara, "Jaringan Wireless di Dunia Berkembang," Creative Commons Licence, vol. 3, 2007.

[7] S. M. Ross and G. R. Morrison, "Experimental research methods," Handbook of research on educational communications and technology, vol. 2, pp. 1021-43, 2004.

[8] F. P. NIST, "140-2,“," Security requirements for cryptographic modules, 2001.

[9] Y. Arta, E. A. Kadir, and D. Suryani, "KNOPPIX: Parallel computer design and results comparison speed analysis used AMDAHL theory," in Information and Communication Technology (ICoICT), 2016 4th International Conference on, 2016, pp. 1-5.

[10] Y. Arta, A. Syukur, and R. Kharisma, "Simulasi Implementasi Intrusion Prevention System (IPS) Pada Router Mikrotik," IT J. Res. Dev., vol. 3, no. 1, pp. 94-104, 2018.

[11] Y. Arta, "Penerapan Metode Round Robin Pada Jaringan Multihoming Di Computer Cluster," Inf. Technol. J. Res. Dev., vol. 1, no. 2, pp. 26-35, 2017. 